\title{
Degradation of dietary fibre polysaccharides of rye in the intestinal tract of growing pigs used as a model animal for studying digestion in humans
}

\author{
Małgorzata Cyran', Maria Rakowska ${ }^{1}$, Justyna Wasilewko ${ }^{2}$ \\ and Lucyna Buraczewska ${ }^{2}$ \\ 'Institute of Plant Breeding and Acclimatization, \\ Radzikow, 05-870 Blonie, Poland \\ 2 The Kielanowski Institute of Animal Physiology and Nutrition, \\ Polish Academy of Sciences \\ 05-110 Jablonna, Poland
}

(Received 26 January 1995; accepted 22 August 1995)

\section{ABSTRACT}

Ileal and faccal excretion of the non-ccllulosic components of the dietary fibre was studied in cannulated pigs fed wheat (control) and two inbred lines of rye with low and high $(3.8 \%$ and $5.6 \%)$ level of soluble dietary fiber (SDF). As compared to the intake, the major fiber components arabinose and xylose were excreted in the ileal digesta in 81.9 and $81.8 \%$ after feeding with low-SDF rye and in 79.3 and $79.5 \%$ when wheat was fed to the animals. Significantly lower fiber degradation was observed after feeding pigs with high-SDF rye; the recovered arabinose and xylose amounted to 93.3 and $90.6 \%$. It was also found that in the small intestine both sugars disappeared to the similar extent. Unlike in the ileal digesta, in faeces the lowest excretion of arabinose and xylose was observed after feeding pigs with high SDF rye (44.0 and $22.7 \%$ ), the highest when wheat was fed ( 52.3 and $32.1 \%$ ) and intermediate for low-SDF rye $(49.2 \%$ and $28.3 \%)$. Whatever the diet, xylose was disappearing in a higher proportion than arabinose. Glucose absorption in the small intestine was notably influenced by the diets; more was found in the digesta after feeding ryes ( 14.5 and $11.2 \%$ ) than wheat $(6.6 \%$ of the intake). This can be explained by different viscosity of the cereals. It was estimated that glucose recovered in the digesta originated in about $69 \%$ from starch. Only trace amounts of glucose were found in faeces.

KEY WORDS: non-cellulosic polysaccharides, dietary fibre, ileal degradation, large intestinal degradation, wheat, rye

\section{INTRODUCTION}

Dietary fibre (DF) is defined as the plant polysaccharides and lignin, which are resistant to hydrolysis by the digestive enzymes of monogastrics (Trowell et 
al., 1976). For analytical purposes the term DF refers mainly to non-starch polysaccharides (NSP) and lignin, but in fact they form a heterogenous complexes with proteins, cutin, waxes, phenolic esters and inorganic constituents (Selvendran et al., 1987). The main components of cereal NSP are arabinoxylans (pentosans), which constitute about $10 \%$ of dry matter in rye (Antoniou et al., 1981 ) and 5.7-8.2\% in wheat (Annison, 1990). The arabinoxylans of rye, in comparison with those of wheat, are more branched and have much higher (2-3 times) content of soluble fraction (Hoseney, 1984). Soluble arabinoxylans of cereals possess anti-nutritive activity, when present in diets for monogastric animals, especially for broiler chicken (Rakowska et al., 1992; Annison, 1990). It is connected with their ability to form highly viscous water solutions (Meuser and Suckow, 1986). On the other hand, these properties determine rheological behavior of doughs and the texture of bakery products (Delcour et al., 1991) as well as beneficial effects in the prevention of certain gastrointestinal and vascular diseases (Roehrig, 1988). In the digestive tract of man and monogastric animals, NSP are degraded by bacterial enzymes into monosaccharides, which are the main energy substrates for bacterial fermentation (Cummings et al., 1986; Bach Knudsen et al., 1991). The end-products of fermentation are: lactic acid in the stomach and in the small intestine, short-chain fatty acids and gases which predominate in the large intestine (Clemens et al., 1975). The extent of microbial breakdown of NSP is influenced by many factors such as composition of NSP-fractions, degree of cell wall lignification, structure and size of particles, an amount of bound silicon, DF intake, other ingredients of a diet (starch), processing of foods and feeds, digesta transit time and number and types of bacteria in the intestinal tract (Selvendran et al.,1987).

According to Moughan et al. (1994) there are marked similarities between the pig and the human in the morphology and function of the digestive tracts. The authors presented many inter-species comparisons of nutrient digestion making a case for the pig as a model animal in human nutrition studies.

The present work was undertaken to characterise polysaccharide fractions and to study the rate of degradation of non-cellulosic polysaccharides (NCP) of two inbred lines of rye differing in soluble dietary fibre and wheat (control cereal) along the digestive tract of pigs.

\section{MATERIAL AND METHODS}

\section{Pigs and diets}

The grain of two inbred lines of rye containing different levels of soluble dietary fibre (SDF) and of wheat used as a control (produced the same year on 
close fields) were fed to five Large White $x$ Landrace castrated male pigs, within their body weight from 30 to $50 \mathrm{~kg}$. Before the experiment a simple $22 \mathrm{~mm}$ diameter $\mathrm{T}$-shape cannula was inserted into the terminal ileum of the pigs. The diets consisted of ground cereals $(96.5 \%)$, mineral and vitamins mixtures and lysine as well as chromium oxide, used as a marker $(0.30 \%$, Table 1$)$. Each diet was given to five pigs according to cross-over design at the level of 2.7 times their assumed maintenance requirement for energy $\left(2.7 \times 500 \mathrm{~kJ} \mathrm{ME} / \mathrm{kg} \mathrm{W}^{0.75}\right)$. The animals were kept in metabolism cages and fed at $12 \mathrm{~h}$ intervals. After a 7-day preliminary period, the faeces were collected continuously over $72 \mathrm{~h}$ and then the digesta for $36 \mathrm{~h}$; the collected materials were immediately frozen.

TABLE 1

Composition of diets, $\%$

\begin{tabular}{|c|c|c|}
\hline \multirow[b]{2}{*}{ Components } & \multicolumn{2}{|c|}{ Diets } \\
\hline & Rye & Wheal \\
\hline Ryc/wheat grain & 96.60 & 96.50 \\
\hline Dicalcium phosphate & 1.00 & 1.00 \\
\hline Limestone & 1.00 & 1.00 \\
\hline Polfamix $P^{1}$ & 0.50 & 0.50 \\
\hline Salt & 0.33 & 0.33 \\
\hline L-Lys-HCl & 0.27 & 0.37 \\
\hline $\mathrm{Cr}_{2} \mathrm{O}_{3}$ & 0.30 & 0.30 \\
\hline
\end{tabular}

\section{Chemical analysis}

The samples from each animal were pooled and freeze-dried prior to analyses. Dry matter was estimated by oven-drying to constant weight at $105^{\circ} \mathrm{C}$. Chromic oxide was analysed according to Kimura and Miller (1957). Soluble and insoluble dietary fiber fractions were isolated from diets by gravimetric method based on enzymic digestion of starch and protein as described by Asp et al.(1983). DF fractions from diets, digesta and faeces were hydrolysed in $1 \mathrm{~N} \mathrm{TFA} \mathrm{at} 125^{\circ} \mathrm{C}$ for $1 \mathrm{~h}$ to measure non-cellulosic polysaccharides. Aldononitrile acetate derivatives of neutral sugars were obtained according to McGinnis (1982). The samples were analysed using Varian 3700 gas chromatograph, equipped with hydrogen flame ionization detector and DB-WAX wide bore capillary column. For calculation of individual monosaccharides in the samples, the correction 
factors were used for losses during hydrolysis and derivatization, and for response on the gas chromatography. Allose was used as an internal standard. The values obtained were expressed as polysaccharides by multiplying pentoses with 0.88 and hexoses with 0.90 . Klason lignin was measured gravimetrically according to Theander and Westerlund (1986). Starch was assayed by enzymic method ( $\AA$ man and Hesselman, 1984), followed by the chromatographic estimation of glucose. Viscosity of the suspensions of cereal flours in $0.2 \mathrm{M}$ sodium phosphate buffer, $\mathrm{pH} 5.6(1: 3 \mathrm{w} / \mathrm{v})$ was measured with Rheotest-2 at constant temperature $\left(30^{0}\right)$.

\section{Statistics}

Analysis of variance was performed using microcomputer statistical programme for data analysis (Agro). Differences were considered significant at $\mathrm{P}<0.05$.

\section{RESULTS AND DISCUSSION}

\section{Content and composition of dietary fibre fractions of cereals}

The results given in Table 2 show that the amount of SDF found in low-SDF rye was two times higher and in high-SDF rye almost three times higher than that of wheat $(2.0 \% \mathrm{DM})$. The content of total DF, calculated as a sum of insoluble and soluble fractions, found in low- and high-SDF ryes was 19.1 and $22.2 \%$, and only $12.2 \%$ in wheat. These values are in good agreement with those reported by Plaami et al. (1989) for rye and reported by Nyman et al. (1984) for wheat. Non-cellulosic polysaccharides comprised $7.8 \%$ of dry matter in wheat but 13.2 and $16.7 \%$ in the low- and high-SDF ryes. In these cereals arabinoxylans (sum of arabinose and xylose) were the main NCP constituent (from 75.1 to $76.2 \%$ ), together with non-cellulosic glucose. Mannose occurred in the amount of $1.5,3.1$ and $2.9 \%$, whereas level of galactose was somewhat higher and made up 5.0,4.8 and $4.0 \%$ of NCP of wheat, low- and high-SDF ryes, respectively. Soluble polysaccharides constituted $21.1,26.0$ and $32.7 \%$ of total NCP found in the mentioned cereals. Composition of SDF of rye is consistent with the results reported by Bengtsson et al. (1992) and the results for NCP composition and lignin content of wheat are in agreement with those obtained by Nyman et al. (1987) as well as by Theander and Westerlund (1986).

Suspension of the high-SDF rye flour had threefold higher viscosity than that of low-SDF rye (1270 mPa-s) and many times higher than that of wheat. 


\section{Ileal excretion of non-cellulosic polysaccharides}

No significant differences were observed between ileal excretion of arabinose (81.9 and $79.3 \%$ of intake) and xylose (81.8 and 79.5\%) after feeding low-SDF rye or wheat diet (Table 3 ), and the sugars disappeared to the same extent in the small intestine. After feeding pigs with high-SDF rye diet arabinoxylans were poorly degraded and arabinose and xylose were highly recovered (93.3 and $90.6 \%$ ) in the digesta. It was notable, that the ratio of xylose to arabinose in the diets $(1.54,1.47,1.64)$ and in the corresponding digesta were similar $(1.55,1.48$ and 1.64 for wheat and for low- and high-SDF ryes, respectively), however, the values differed among the cereals. These results might be referred not only to higher level of NCP in rye, but also to the structural differences of soluble arabinoxylans existing in different rye strains (Bengtsson et al.,1992).

There were no significant differences between ileal recovery of mannose from wheat $(91.7 \%)$ and high-SDF rye $(87.2 \%)$ diets. The respective value for low-SDF rye diet was significantly lower $(80.8 \%)$. Very low degradation in the small intestine was observed for polysaccharides containing galactose; after feeding pigs with rye diets the sugar was recovered in about $97 \%$ and after wheat diet in $92 \%$.

The values of glucose recovery were only $6.6,11.2$ and $14.5 \%$ in the ileal digesta of pigs fed with wheat and with low- and high-SDF rye diets, respectively. It is worthy to note, that the level of total glucose recovered in the digesta after feeding all the diets was three times higher than the level of non-cellulosic glucose, recovered in starch-depleted DF fractions of the cereal flours (Table 2), deriving mainly from $\beta$-glucans. These results indicate, that the part of glucose originated from starch constituted significant amount of residual glucose (on average $69 \%$ ) found at the end of the small intestine. It is supposed that higher SDF level in diets may decrease starch digestibility, irrespective of its level in the cereals (Table 2). According to Englyst and Cummings (1993) cereal starch is classified as slowly but completely digestible, although existing physically inaccessible form of starch, enclosured within particle structures of milled grain, seems to be major reason of incomplete starch digestion in the case of wheat diet. As compared to wheat, two-three times higher amount of SDF in rye, with its ability to form viscous solutions (Table 2) seems to be also important reason for uncomplete digestibility of starch. In human beings this might be of medical importance, especially in respect to diabetics. Similar results were obtained by Jenkins et al. $(1977,1980)$ with guar gum and guar-enriched breads used for human consumption. Studies on pigs and men have demonstrated that increasing intake of certain fibers, particularly those creating highly viscous condition in the intestine, can modify the secretion of some hormones, including insulin, glucagon, gastric inhibitory polypeptide and possibly cholecystokinin 
TABLE 2

Composition and content of dietary fibre and starch in wheat and rye grains (\% of dry matter) and viscosity of the cereal flours

\begin{tabular}{|c|c|c|c|c|c|c|}
\hline & \multicolumn{2}{|c|}{ Wheat } & \multicolumn{2}{|c|}{ Low-SDF rye } & \multicolumn{2}{|c|}{ High-SDF rye } \\
\hline \multicolumn{7}{|l|}{ Dietary fibre } \\
\hline Insoluble & \multicolumn{2}{|c|}{10.16} & \multicolumn{2}{|c|}{15.30} & \multicolumn{2}{|c|}{16.56} \\
\hline Soluble & \multicolumn{2}{|c|}{2.00} & \multicolumn{2}{|c|}{3.80} & \multicolumn{2}{|c|}{5.60} \\
\hline Total & \multicolumn{2}{|c|}{12.16} & \multicolumn{2}{|c|}{19.10} & \multicolumn{2}{|c|}{22.16} \\
\hline \multicolumn{7}{|c|}{ Non-cellulosic polysaccharides } \\
\hline Arabinose & 2.30 & $(0.35)^{\prime}$ & 3.77 & $(0.89)$ & 4.82 & $(1.50)$ \\
\hline Xylose & 3.55 & $(0.58)$ & 5.59 & $(1.47)$ & 7.92 & $(2.78)$ \\
\hline Mannose & 0.12 & $(0.04)$ & 0.41 & $(0.14)$ & 0.49 & $(0.14)$ \\
\hline Galactose & 0.41 & $(0.24)$ & 0.63 & $(0.22)$ & 0.67 & $(0.25)$ \\
\hline Glucose & 1.40 & $(0.44)$ & 2.75 & $(0.68)$ & 2.82 & $(0.79)$ \\
\hline Total NCP & 7.78 & $(1.65)$ & 13.15 & $(3.42)$ & 16.72 & $(5.46)$ \\
\hline Klason lignin & \multicolumn{2}{|c|}{2.13} & \multicolumn{2}{|c|}{2.89} & \multicolumn{2}{|c|}{3.18} \\
\hline Starch & \multicolumn{2}{|c|}{71.82} & \multicolumn{2}{|c|}{67.52} & \multicolumn{2}{|c|}{65.10} \\
\hline Viscosity? & \multicolumn{2}{|c|}{24} & \multicolumn{2}{|c|}{1270} & \multicolumn{2}{|c|}{4284} \\
\hline
\end{tabular}

'values in parentheses represent soluble fraction expressed in $\% \mathrm{DM}$

2 expressed in $\mathrm{mPa}-\mathrm{s}$

TABLE 3

Ileal digesta content ( $\%$ of dry matter) and excretion ( $\%$ of intake) of sugars after feeding pigs with cereal diets

\begin{tabular}{|c|c|c|c|c|c|c|}
\hline & \multicolumn{6}{|c|}{ Diets } \\
\hline & \multicolumn{2}{|c|}{ Wheat } & \multicolumn{2}{|c|}{ Low-SDF rye } & \multicolumn{2}{|c|}{ High-SDF ryc } \\
\hline & Content & Excretion & Content & Excretion & Content & Excretion \\
\hline Arabinose & 1.76 & $79.3^{\mathrm{A}}$ & 2.98 & $81.9^{A}$ & 4.35 & $93.3^{\mathrm{B}}$ \\
\hline Xylose & 2.73 & $79.5^{\mathrm{A}}$ & 4.42 & $81.8^{\mathrm{A}}$ & 6.93 & $90.6^{\mathrm{B}}$ \\
\hline Mannose & 0.11 & $91.7^{\wedge}$ & 0.32 & $80.0^{\mathrm{B}}$ & 0.41 & $87.2^{\wedge}$ \\
\hline Galactose & 0.37 & $92.2^{\mathrm{i}}$ & 0.59 & $96.7^{b}$ & 0.63 & $96.9^{\mathfrak{b}}$ \\
\hline Glucoset & 4.66 & $6.6^{\mathrm{A}}$ & 7.63 & $11.2^{B}$ & 9.53 & $14.5^{\circ}$ \\
\hline
\end{tabular}

' sum of noncellulosic glucose and of residual starch glucose

$a, b, c-P \leqslant 0.05$

A, B, C $-\mathrm{P} \leqslant 0.01$ 
(Vahouny and Cassidy, 1985). A lower postprandial glycaemic response as well as reduction of serum cholesterol are related to fibre viscosity (Graham and Åman, 1991) which reduces both the rate and extent of absorption from the small intestine.

The present study indicates that there is, though limited, degradation of NCP in the upper part of the digestive tract of pigs, what is in agreement with other findings (Bach Knudsen et al., 1991; Graham et al., 1986). Some degradation of easily fermentable dietary fiber components, such as arabinoxylans and $\beta$-glucans was also observed in the small intestine of men by Åman et al. (1994).

\section{Faecal excretion of non-cellulosic polysaccharides}

In contrast to low degradation found in the upper part of the digestive tract, much higher breakdown of NCP was observed in the large intestine, where the residual glucose disappeared to the highest extent (Table 4). There were no differences in faecal excretion of this sugar between rye diets $(1.0$ and $1.0 \%)$, while it was negligible $(0.5 \%)$ for wheat diet. The lowest faecal excretion of arabinose $(44.0 \%)$ was found for high-SDF rye diet and it was significantly different from those found for low-SDF rye and wheat diets $(49.2$ and $52.3 \%$, respectively). In contrast to the ileal, the faecal excretion of xylose was notable lower $(22.7,28.3$ and $32.1 \%$, after feeding wheat, low- and high-SDF rye diets) as compared to the respective values of arabinose.

The above findings suggest, that microflora of the large intestine depolimerizes the main xylan chain, leaving arabinose substituents attached to the xylose monomers, since xylose to arabinose ratio decreased to $0.95,0.85$ and 0.85 , for wheat, low- and high-SDF rye diets, respectively. These results are similar to

TABLE 4

Faccal content ( $\%$ of dry matter) and excretion ( $\%$ of intake) of sugars after feeding pigs with cereal diets

\begin{tabular}{|c|c|c|c|c|c|c|}
\hline & \multicolumn{6}{|c|}{ Diets } \\
\hline & \multicolumn{2}{|c|}{ Wheat } & \multicolumn{2}{|c|}{ Low-SDF rye } & \multicolumn{2}{|c|}{ High-SDF rye } \\
\hline & Content & Excretion & Content & Excretion & Content & Excretion \\
\hline Arabinose & 1.16 & $52.3^{\mathrm{A}}$ & 1.79 & $49.2^{B}$ & 2.05 & $44.0^{\circ}$ \\
\hline Xylose & 1.10 & $32.1^{\mathrm{A}}$ & 1.53 & $28.3^{B}$ & 1.74 & $22.7^{\mathrm{C}}$ \\
\hline Mannose & 0.04 & $33.3^{\mathrm{A}}$ & 0.05 & $12.5^{\mathrm{B}}$ & 0.06 & $12.8^{\mathrm{B}}$ \\
\hline Galactose & 0.20 & $50.0^{\mathrm{a}}$ & 0.36 & $59.0^{6}$ & 0.37 & $56.9^{b}$ \\
\hline Glucose $^{1}$ & 0.31 & $0.5^{\mathrm{A}}$ & 0.67 & $1.0^{\mathrm{B}}$ & 0.67 & $1.0^{\mathrm{H}}$ \\
\hline
\end{tabular}

' sum of non-cellulosic glucose and of glucose originated from starch mean values within a row with the same superscript letter were not significantly different;

$\mathrm{P} \leqslant 0.01$ for $\mathrm{a}, \mathrm{b}, \mathrm{c}$ and $\mathrm{P} \leqslant 0.05$ for $\mathrm{A}, \mathrm{B}$ 
those obtained by Björck et al.(1984), who reported decrease of xylose to arabinose ratio from 1.55 calculated in a diet to 1.13 estimated in faeces of rats fed wheat grain. The highest degradation of arabinoxylans after feeding pigs with high-SDF rye diet can be related to its higher level of SDF, which is more available to bacterial degradation (Nyman, 1985). Although the fermentation of the fibre by the microflora of the large intestine is not limited to its soluble fraction, in fact some soluble fibres are only partially fermented (Wursch, 1991). The faecal excretion of galactose was $50.0,59.0$ and $56.9 \%$ and of mannose was $33.3,12.5$ and $12.8 \%$, respectively for wheat and low- and high-SDF rye diets. Degradation of their polymers followed the same tendency as that of arabinoxylans.

In the large intestine, where the digesta may be retained for prolonged periods of time, allowing prolific microbial growth (Anugwa et al., 1989), the NCP of high-SDF rye were fermented to higher extent than of the other cereals. This can be related to higher level of short chain fatty acids (SCFA) which are the principal end-products of fibre degradation in the large intestine of various mammals, including humans (Cummings et al., 1987). Most of the SCFA are absorbed through the colonic mucosa and may contribute to human energy supply. Up to $70-75 \%$ of polysaccharide energy may become available for human metabolism (Wisker et al., 1988). It should be noticed, that SCFA production occurs always, even when no dietary carbohydrate or fibre is ingested, because intestinal mucus and other endogenous materials containing aminosugars and sugars are also fermented (Åman et al., 1994).

Higher proportion of DF which is resistant to microbial degradation, in comparison with more easily fermented sugars, usually have a greater faecal bulking effect, adsorb and dilute the possible mutagens and tumor promoters as well as reduce the transit time. All these properties decrease the incidence of colon cancer (Schweizer and Wursch,1986). Moreover, it has been shown that resistant type of fibre adsorb bile acids and influence their metabolism (Wursch, 1991).

Assuming that growing pigs are good model animal for humans, it can be concluded that inclusion of optimal proportion of rye with high-SDF content into human diets (breakfast cereals and breads) may have a beneficial effect in prevention of civilization diseases. 


\section{REFERENCES}

Åman, P., Hesselman, K., 1984. Analysis of starch and other main constituents of cereal grains. Swedish J. Agric. Res. 14, 135-139

Åman, P., Zhang, J. X., Hallmans, G., Lundin, E., 1994. Excretion and degradation of dietary fiber constituents in ileostomy subjects consuming a low fiber diet with and without brewer's spent grain. J. Nurt. 124, 359-363

Annison, G., 1990. Polysaccharide composition of Australian wheats and the digestibility of their starches in broiler chicken diets. Aust. J. Exp. Agric. 30, 183-186

Antoniou, T., Marquardt, R.R., Cansfield, P.E., 1981. Isolation, partial characterization, and antinutritional activity of a factor (pentosans) in rye grain. J. Agric. Food Chem. 29, 1240-1247

Anugwa, F.O.I., Varel, V.H., Dickson, J.S., Pond, W.G., Krook, L.P., 1989. Effects of dietary fiber and protein concentration on growth, feed efficiency, visceral organ weights and large intestine microbial populations of swine. J. Nutr. 119, 879-886

Asp, N.G., Johansson, C.G., Hallmer, H., Siljeström, M., 1983. Rapid enzymatic assay of insoluble and soluble dietary fibre. J. Agric. Food Chem. 31, 476-482

Bach Knudsen, K.E., Jensen, B.B., Andersen, J.O., Hansen, I., 1991. Gastrointestinal implications in pigs of wheat and oat fractions. 2. Microbial activity in the gastrointestinal tract. Brit. J. Nutr. $65,233-248$

Bengtsson, S., Andersson, R., Westerlund, E., Åman, P., 1992. Content, structure and viscosity of soluble arabinoxylans in rye grain from several countries. J. Sci. Food Agric. 58, 331-337

Björck, I., Nemine, M., Asp, N.G., 1984. Extrusion cooking and dietary fiber: effects on dietary fiber content and degradation in the rat intestinal tract. Cereal Chem. 61, 174-179

Clemens, E.T., Stevens, C.E., Southworth, M., 1975. Sites of organic acid production and pattern of digesta movement in the gastrointestinal tract of swine. J. Nutr. 105, 759-768

Cummings, J.H., Englyst, H.N., Wiggins, H.S., 1986. The role of carbohydrates in lower gut function. Nutr. Rev. 44, 50-54

Cummings, J.H., Pomare, E.W., Branch, W.J., 1987. Short chain fatty acids in human large intestine, portal, hepatic and venous blood. Gut 28, 1221-1227

Delcour, J.A., Vanhamel, S., Hoseney, R.C., 1991. Physicochemical and functional properties of rye nonstarch polysaccharides. II. Impact of a fraction containing water-soluble pentosans and proteins on gluten-starch loaf volumes. Cereal Chem. 68, 72-76

Englyst, H.N., Cummings, J.H., 1993. Nutritional classification of starch and its validation by studies in man. Proc. Intern. Symp. on Nutritional, Chemical and Food Processing Implications of Nutrient Availability, Ettlingen, May 912, 142-145

Graham, H., Hesselman, K., Johnsson, E., Åman, P., 1986. Influence of $\beta$-glucanase supplementation on digestion of a barley-based diet in the pig gastrointestinal tract. Nutr. Rep. Int. 34, 1089-1096

Graham, H., Åman, P., 1991. Nutritional aspects of dietary fibres. Anim. Feed Sci. Technol. 32, $143-158$

Hoseney, R.C., 1984. Functional properties of pentosans in baked foods. Food Technol. 38, 114-117

Jenkins, D.J.A., Leeds, A.R., Gassull, M.A., Cochet, B., Alberti, K.G.M., 1977. Decrease in post-prandial insulin and glucose concentrations by guar. Ann. Intern. Med, 86, 83-132

Jenkins, D.J.A., Wolever, T.M.S., Taylor, R.H., Barker, H.M., Fielden, H., Jenkins, A.L., 1980c. Effect of guar crispbread with cereal products and leguminous seeds on blood glucose concentrations of diabetics. Brit. Med. J. 281, 1248-1250

Kimura, F.T., Miller, V.L., 1957. Improved determination of chromic oxide in cow feed and faeces. Agric. Food Chem. 5, 216 
McGinnis, G., 1982. Preparation of aldononitrile acetates using $\mathrm{N}$-methylimidazole as catalyst and solvent. Carbohydr. Res. 108, 294-292

Meuser, F., Suckow, P., 1986. Non-starch polysaccharides. Spec. Publ. R. Soc. Chem. 42-61

Moughan, P.J., Cranwell, P.D., Darragh, A.J., Rowan, A.M., 1994. The domestic pig as a model animal for studying digestion in humans. In: W.B. Souffrant, H.Hagemeister (Editors) Proceeding VIth International Symposium on Digestive Physiology in Pigs, Bad Doberan, pp. 389-397

Nyman, M., Siljestörm, M., Pedersen, B., Bach Knudsen, K.E., Asp, N.G., Johansson, C.G., Eggum, B.J., 1984. Dietary fiber content and composition in six cereals at different extraction rates. Cereal Chem. 61, 14-19

Nyman, M., 1985. Fermentation of dietary fiber in the intestinal tract. PhD dissertation, University of Lund, Sweden

Nyman, M., Björck, I., Hakansson, B., Asp, N.G., 1987. Popping of whole-grain wheat: Effects on dietary fibre degradation in the rat intestinal tract. J. Cereal Sci. 5, 67-72

Plaami, S., Saastamoinen, M., Kumpulainen, J., 1989. Effects of variety and environment on dietary fibre content of winter rye in Finland. J. Cereal Sci. 10, 209-215

Rakowska, M., Kupiec, R., Rybka, K., 1992. Studies on the antinutritive components in the ryc grain. VI. Effect of dietary fiber fraction on protein digestibility in rats. Pol. J. Food Nutr. Sci. $1 / 42,103-107$

Roehrig, K.L., 1988. The physiological effects of dietary fiber - a review. Food Hydrocolloids 2, 1-18

Schweizer, T.F., Wursch, P., 1986. Dietary fiber and the prevention of cancer. Nestle Res. News $43+52$

Selvendran, R.R., Stevens, B.J.H., Du Pont, M.S., 1987. Dietary fiber: chemistry, analysis, and properties. In: C.O. Chichester, E.M. Mrak, B.S. Schweigert (Editors), Advances in food research. Academic Press, New York, Vol. 31

Theander, O., Westerlund, E.A., 1986. Studies on dietary fiber. 3. Improved procedures for analysis of dietary fiber. J. Agric. Food Chem. 34, 330-336

Trowell, H., Southgate, D.A.T., Wolever, T.M.S., Leeds, A.R., Gassull, M.A., Jenkins, D.J.A., 1976. Dietary fibre redefined. Lancet 1, 967

Vahouny, G. V., Cassidy, M.M., 1985. Dietary fibers and absorption of nutrients. Proc. Exp. Biol. Med. 180, 432-446

Wisker, E., Maltz, A., Feldheim, W., 1988. Metabolizable energy of diets low or high in dietary fiber from cereals when eaten by humans. J. Nutr. 118, 945-952

Wursch, P., 1991. Dictary fiber and unabsorbed carbohydrates. In: M. Gracey, N. Kretchmer, E. Rossi (Editor). Sugars in nutrition. Vevey/Raven Press, Ltd., New York, pp. 153-168

\section{STRESZCZENIE}

Rozkład polisacharydów włókna pokarmowego żyta w przewodzie pokarmowym rosnących świń użytych jako zwierzę modelowe do badań trawienia u ludzi

Oznaczono stopień rozkładu niccelulozowych polisacharydów włókna pokarmowego do końca jelita cienkiego oraz w całym przewodzie pokarmowym rosnących świń, karmionych pszenicą (dieta kontrolna) oraz żytem $\mathrm{z}$ dwóch wsobnych linii o zróżnicowanej zawartości rozpuszczalnego w!ókna pokarmowego (SDF). Zawartość arabinozy i ksylozy wyrażona procentowo w stosunku do ilości spożytej nie różniła się istotnie w treści z końca jelita cienkiego świń karmionych dietą pszenną $(79,3$ i $79,5 \%$ ) oraz żytnią o niskiej zawartości SDF $(81,9$ i $81.8 \%$,). Natomiast w przypadku diety żytniej 
o wysokiej zawartości SDF wartości te były znacznie wyższe $(\mathrm{P}<0,01 ; 93,3$ i $90,6 \%)$. W kale natomiast stwierdzono najniższe wydalanie arabinozy i ksylozy w stosunku do ilości spożytej w przypadku żywienia dietą żytnią o wysokiej zawartości SDF $(44,0$ i 22,7\%), a istotnie wyższe $(\mathrm{P}<0,01)$ przy żywieniu dietą żytnią o niskiej zawartości SDF $(49,2$ i $28,3 \%)$ oraz dietą pszenną $(52,3$ i $32,1 \%$ ). Ubytek ksylozy byl znacznie wiçkszy (około $20 \%$ ) niż arabinozy przy żywieniu wszystkimi zbożami. Zawartość glukozy w składnikach treści jelita cienkiego była najniższa po podaniu diety pszennej i wynosila $6,6 \%$ glukozy spożytej, glównie w postaci skrobi; w przypadku diet żytnich obserwowano znacznie wyższą jej zawartość, stanowiącą 11,2 i 14.5\% ilości pobranej odpowiednio w diecie o niskiej i wysokiej zawartości SDF. Glukoza pochodząca ze skrobi stanowiła przeciętnie $69 \%$ ogólnej jej zawartości w treści z końca jelita cienkiego. W kale stwierdzono tylko śladowe ilości badanych składników zawierających glukozę. Przypuszcza się, że na degradację niecelulozowych polisacharydów wlókna pokarmowego wpływa nie tylko zawartość SDF w ziarnie zbóż, ale także zróżnicowana struktura tych polimerów.

Wydaje się, że żyto o większej zawartości SDF, wykazując wyższą lepkość i wolniejszy rozkład polisacharydów w jelicie cienkim, może stanowić korzystniejszy składnik pokarmu ludzi, zapobiegając chorobom objawiającym się zbyt wysokim poziomem glukozy, czy cholestcrolu, lub lagodząc ich przebieg. 